DOI: $10.17223 / 18572685 / 45 / 2$

\title{
ОТ РЕДАКТОРА ВЫПУСКА
}

В данном номере журнала представлены статьи, подготовленные участниками Всероссийской научной конференции с международным участием «Славянские языки в условиях современных вызовов», проходившей 13-14 мая 2016 г. в Томском государственном университете. Организаторами конференции выступили Национальный исследовательский Томский государственный университет (г. Томск, Россия), Общественная ассоциация «Русь» (г. Кишинев, Молдова) и редакция международного исторического журнала «Русин».

Программный комитет, возглавляемый профессором Томского государственного университета Л.П. Дроновой и редактором международного исторического журнала «Русин» С.Г. Суляком, и организационный комитет под руководством профессора 3.И. Резановой стремились к созданию условий эффективного обсуждения актуальных научных проблем существования славянских языков в современном активно изменяющемся мире.

Проблемное поле обсуждений конференции включало широкий круг вопросов, касающихся не только современного состояния славянских языков, установления онтологии и функционирования единиц разных уровней языковой системы, но и процессов их исторической динамики. Важное направление анализа славянских идиомов, представленное в докладах конференции, - анализ исторического, культурного, социального контекста языковой динамики, разнонаправленных межславянских контактов и взаимовлияний.

Одна из задач организаторов конференции - создание условий междисциплинарного научного диалога, необходимого для плодотворного сотрудничества разных направлений гуманитарной науки. Основой данного диалога явилось обсуждение докладов, представляющих результаты исследований, выполненных не только с использованием собственно языковых данных и лингвистических методов их интерпретации, но и с привлечением данных истории, культуры, этнографии народов и культур славянского мира. В этом аспекте хотелось бы отметить значительный позитивный эффект от личного участия в работе конференции редактора журнала «Русин» С.Г. Суляка, который представил доклад, посвященный историографии исследований языка славяно-молдавских грамот XIV-XVII вв.*

\footnotetext{
* Статья по материалам доклада опубликована в «Вестнике Томского государственного университета. Филология» (Суляк 2016).
} 
Важной задачей являлось также привлечение к дискуссии в рамках конференции исследователей, работающих не только с использованием традиционной устоявшейся лингвистической методологии, но и вовлекающих новые исследовательские приемы, притягивающие в исследование новые типы данных. Это направление изучения славянских языков было представлено работами, выполненными с применением корпусных данных, и психолингвистическими исследованиями, проводимыми на основе поведенческих экспериментов и статистической обработки полученных результатов.

Дискуссии участников конференции были организованы в рамкахтрех секций, материалы которых репрезентативно представлены в данном выпуске журнала.

Активное сотрудничество организаторов конференции с редколлегией журнала «Русин», миссия которого - «публикация исследований по истории, культуре и языку русинов (руснаков)», проявилось В том, что в этом году на конференции работала секция «Русинский язык в контексте славянских взаимодействий». Основная направленность докладов участников данной секции - сравнительно-историческое исследование лексики и фразеологии русинского языка. Во всех докладах были представлены результаты анализа семантики и системных связей лексических и фразеологических единиц русинского языка в контексте истории и культурного своеобразия русинского этноса. Ярким примером данного подхода является статья Г.Н. Стариковой «Русинские названия праздников как свидетельство языковой и этнокультурной специфичности народа», написанная по материалам выступления. В публикации автор результативно использует прием культурологического комментария при описании данной лексико-семантической группы, справедливо отмечая, что анализируемая лексика относится к числу культурно маркированной, отражающей в семантике, в коннотативной зоне значения «ценности этноса, тесно связанные с историей его развития, формированием мировосприятия и верований его представителей». В этой, как и в большинстве других, публикации исследуются экстралингвистические этнокультурные факторы формирования своеобразия фрагментов лексических и фразеологических систем русинского языка. Так, анализируя русинские паремии на фоне русского и украинского языков, О.В. Ломакина и В.М. Мокиенко приходят к выводу о различной силе западно- и восточнославянских языковых и культурных влияний на язык русинов. Л.П. Дронова, анализируя лексические средства выражения семантики необходимости в русинском языке, приходит к выводу, что данная лексическая группа свидетельствует о тесных контактах русинского языка с западнославянскими языками. Об этих же тенденциях свидетельствуют и результаты выполненного И.В.Садыковой анализа лексической группы со значением 
тактильных ощущений, имеющей более позднее время формирования в славянских языках по сравнению с лексикой зрительного и слухового восприятия. Аспекты межславянского взаимодействия, отраженные в лексической системе русинского языка, С.А. Толстик рассматриваются сквозь призму лексемы со значением «картавый», имеющей развитую систему синонимических, омонимических и полисемических соответствий в современных славянских языках. Во всех статьях отмечаются свидетельства культурного и языкового контактирования русинов с неславянскими языками региона.

Секция «Социолингвистические и культурологические исследования славянских взаимодействий» представлена в данном выпуске журнала четырьмя статьями. В статье Д.А. Катунина обсуждаются важные социальные проблемы современного существования славянских языков - проблемы языкового законодательства, определяющего социальный статус языковых идиомов. Данная тема активно исследуется Д.А. Катуниным, представляющим результаты мониторинга языковой политики государств относительно различных славянских языков в периодических научных изданиях, в том числе и на страницах журнала «Русин» (Катунин 2012, Катунин 2014). В данном выпуске журнала исследователь представляет результаты анализа того, как отражается социальный статус черногорского языка в языковом законодательстве стран региона.

Е.А. Оглезнева, автор широко известных работ по языку русского восточного зарубежья, представляет результаты сравнительного социологического анализа факторов, обусловивших присутствие русского, украинского, польского и белорусского языков в Китае (в Харбине) в начале XX в., выявляя состав славянских идиомов и их статус.

Анализ этноязыковых контактов славян как экстралингвистическая основа формирования семантики единиц неславянского языка представлен в статье К.А. Шишигина «Славянский адстрат в гибридной глагольно-префиксальной системе идиша», в которой автор доказывает, что современная глагольно-префиксальная система идиша формировалась в условиях системного влияния славянских (и в меньшей мере семитских) словообразовательных моделей.

Акцент на результатах применения новейших методов лингвистических и междисциплинарных исследований современных славянских языков был сделан в докладах секции «Когнитивные и дискурсивные исследования славянских языков». В журнале данная секция представлена двумя статьями. Статья И.В. Тубаловой и Ю.В. Филь «Содержательная интерпретация "советского" в дискурсах русских и чешских СМИ» выполнена с опорой на методологию современного критического дискурс-анализа с привлечением данных национальных корпусов рус- 
ского и чешского языков. Обращение к анализу текстовых репрезентаций идеологически значимого концепта в общественно-политическом контексте современной России и Чехии позволило авторам охарактеризовать не только различие текстовых актуальных смыслов данной лексемы, но и социально-исторические детерминации выявленных различий. В статье 3.И. Резановой и Е.Д. Некрасовой, выполненной в русле когнитивной экспериментальной парадигмы, выявлено различие в когнитивной обработке категории конкретности-абстрактности, имеющей в сравниваемых языках близкое, но не тождественное формальное маркирование.

Таким образом, можно констатировать, что сотрудничество организаторов конференции «Славянские языки в условиях современных вызовов» с редколлегией журнала «Русин» оказалось плодотворным и содействовало консолидации славистов на изучении разных аспектов межславянского языкового взаимодействия с использованием широкого спектра междисциплинарных методов, привлекло внимание к изучению русинского языка, прежде всего его в сравнительно-историческом аспекте.

Председатель оргкомитета конференции, профессор, зав. кафедрой общего, славяно-русского языкознания и классической филологии Томского государственного университета, член редколлегии журнала «Русин» 3.И. Резанова

\section{ЛИТЕРАТУРА}

Катунин 2012 - Катунин Д.А. Языковое законодательство Косова и Метохии в постсоциалистический период: сербская версия // Вестник Томского государственного университета. 2012. № 365. С. 19-24.

Катунин 2014 - Катунин Д.А. Русинский и словацкий языки в современном законодательстве Хорватии // Русин. 2014. № 2 (36). С. 296-311.

Суляк 2016 - Суляк С.Г. О языке славяно-молдавских грамот XIV-XVII вв. (к историографии вопроса) // Вестник Томского государственного университета. Филология. 2016. № 4 (42). C. 73-97. DOI: 10.17223/19986645/42/72016 


\section{EDITORIAL}

This issue contains articles written by the participants of the AllRussian Conference with International Participation "Slavic Languages: Responding to New Challenges" held in Tomsk State University on May 13-14, 2016. The conference was organized by National Research Tomsk State University (Tomsk, Russia), Public Association "Rus'” (Chișinău, Moldova) and the Editorial Board of Rusin International Historical Journal.

The Program Committee chaired by Professor of Tomsk State University L.P. Dronova and the editor of Rusin International Historical Journal S.G. Sulyak, and the Organizing Committee led by Professor Z.I. Rezanova sought to create the best atmosphere for effective academic discussion of topical problems of modern Slavic languages in the actively changing world.

The discussion focused on a wide range of issues relating the current state of the Slavic languages, the ontology and functioning of the units at various levels of the language system, and their historical dynamics. An important trend in the research of Slavic idioms represented at the conference was the analysis of the historical, cultural and social context of language dynamics, various Slavic contacts and mutual influences.

The conference aimed at providing conditions for interdisciplinary academic dialogue needed for fruitful cooperation of different branches of humanities. This dialogue was based on the discussion of reports representing the results of studies carried out on the basis of language data and linguistic methods of their interpretation as well as using the data of history, culture, and ethnography of the Slavic world. An important contribution in this regard was provided by S.G. Sulyak, the chief editor of Rusin, who represented his report on the historiography of the language studies of the Slavic-Moldavian charters of the 14th17th centuries*.

Another important task was to engage the researchers who work outside the traditional linguistic methodology and use new techniques and new types of data. This direction of the Slavic language studies was presented in the works that used the corpus data as well as psycholinguistic research basing on the behavioral experiments and statistical processing of the results.

The Conference program was composed of three sections, the results of which are presented in this journal.

\footnotetext{
* The article based on this report is published in Tomsk State University Journal of Philology (Sulyak 2016).
} 
The active cooperation between the Conference Board and Rusin International Historical Journal, aimed at publishing the studies in history, culture and language of the Rusins (Rusnaks), resulted in the section "The Rusin language in the context of Slavic interactions", devoted to the comparative and historical studies of vocabulary and phraseology of the Rusin language. The reports represented the analysis of semantics and systemic relations of lexical and phraseological units of the Rusin language in the context of the historical and cultural identity of the Rusin ethnic group, as for instance, in G.N. Starikova's "The names of Rusin holidays as the evidence of linguistic and ethno-cultural specificity of the nation," where the author uses cultural commentary to describe the lexical-semantic group as culturally marked and reflecting in its semantics and connotation "the values of the ethnicity that are closely connected with the history of its development, the formation of the world perception and beliefs." Most of the researchers study the extralinguistic and ethnocultural factors of the specificity of lexical and phraseological systems of the Rusin language. For instance, analyzing the Rusin paroemias compared with the Russian and Ukrainian languages, O.V. Lomakin and V.M. Mokienko come to the conclusion that West and East Slavic languages and cultures had different impact on the Rusin language. L.P. Dronova analyses the lexical means of expressing the semantics of necessity in the Rusin language, comes to the conclusion that this lexical group shows close contacts of the Rusin language with the West Slavic languages. The same results are achieved by I.V. Sadykova, who analyses the lexical group with the meaning of tactile sensations, which has a later time of formation in the Slavic languages compared with the words denoting visual and auditory perception. S.A. Tolstik uses the lexical unit "kartavyy" with its developed system of synonymy, homonymy and polysemy in modern Slavic languages to show the aspects of the Slavic interaction reflected in the lexical system of the Rusin language. All articles discuss the cultural and linguistic contact between the Rusins and the non-Slavs of the region.

The Section "Sociolinguistic studies in Slavic languages" is represented by four articles. D.A. Katunin discuss important social issues of modern Slavic languages - language laws determining the social status of language idioms. D.A. Katunin focuses on the language policy in Slavic-speaking states on the materials of different academic journals, including Rusin (Katunin 2012, Katunin 2014). In this issue the researcher analyses the social status of the Montenegrin language in the language legislation of the countries in this region.

E.A. Oglezneva, the author of well-known works about the language of the Russian Eastern expat community, represents the results of the 
comparative sociological analysis of the factors determining the presence of Russian, Ukrainian, Polish and Belarusian languages in China (Harbin) in the early twentieth century, identifying the composition and status of Slavic idioms.

In his article "The Slavic adstratum in the Yiddish hybrid prefixed verb system" K.A. Shishigin analyses the ethnolinguistic contacts of the Slavs as the extralinguistic basis for the formation of semantics of nonSlavic language units. The author shows that modern Yiddish prefixed verb system formed under the systemic influence of the Slavic and, to a lesser extent, Semitic word-building models.

The Section "Cognitive and discursive studies of Slavic languages" makes an emphasis on the application of the latest methods of linguistic and interdisciplinary research of modern Slavic languages. The article "The content interpretation of the Soviet in the Russian and Czech media disourses" by I.V. Tubalova and Y.V. Fil is based on the methodology of contemporary critical discourse-analysis involving the data from national corpuses of the Russian and Czech languages. The analysis of textual representations of the ideologically meaningful concept in the socio-political context of contemporary Russia and the Czech Republic allowed describing differences in actual text meanings of the lexical unit as well as their socio-historical determinations. Conducting their research within the experimental cognitive paradigm,Z.I Rezanova and E.D. Nekrasova identify the differences in the cognitive processing of the category "abstractedness", which has close, but not identical formal marking in the languages compared.

Thus, it is obvious that the fruitful cooperation of the "Slavic Languages: Responding to New Challenges" Conference Board with the Rusin International Historical Journal promoted the collaboration of Slavicists who study various aspects of the Slavic language interaction using a wide range of interdisciplinary methods. It also attracted the attention to the study of the Rusin language, especially in its comparativehistorical aspect.

Head of the Organizing Committee, Professor, Head of the General Slavonic-Russian Linguistics and Classical Philology Department of Tomsk State University, member of the Rusin Editorial Board Z.I. Rezanova 


\section{REFERENCES}

Katunin, D.A. (2012) Language legislation of Kosovo and Metohija in postsocialist period: Serbian version. Vestnik Tomskogo gosudarstvennogo universiteta - Tomsk State University Journal. 365. pp. 19-24 (In Russian).

Katunin, D.A. (2014) Rusinskiy i slovatskiy yazyki v sovremennom zakonodatel'stve Khorvatii [The Rusinian and Slovak languages in the current legislation of Croatia]. Rusin. 2 (36). pp. 296-311.

Sulyak, S.G. (2016) On the language of the Slavonic-Moldavian documents of the 14th-17th centuries. Vestnik Tomskogo gosudarstvennogo universiteta. Filologiya - Tomsk State University Journal of Philology. 4 (42). pp. 73-97. (In Russian). DOI: 10.17223/19986645/42/72016 